\title{
Bound hand and foot and handed over to the caste Hindus: Ambedkar, untouchability and the politics of Partition
}

DOI:

$10.1177 / 0019464617745925$

\section{Document Version}

Accepted author manuscript

Link to publication record in Manchester Research Explorer

\section{Citation for published version (APA):}

Chairez-Garza, J. (2018). Bound hand and foot and handed over to the caste Hindus: Ambedkar, untouchability and the politics of Partition. Indian Economic \& Social History Review, 55(1), 1-28.

https://doi.org/10.1177/0019464617745925

\section{Published in:}

Indian Economic \& Social History Review

\section{Citing this paper}

Please note that where the full-text provided on Manchester Research Explorer is the Author Accepted Manuscript or Proof version this may differ from the final Published version. If citing, it is advised that you check and use the publisher's definitive version.

\section{General rights}

Copyright and moral rights for the publications made accessible in the Research Explorer are retained by the authors and/or other copyright owners and it is a condition of accessing publications that users recognise and abide by the legal requirements associated with these rights.

\section{Takedown policy}

If you believe that this document breaches copyright please refer to the University of Manchester's Takedown Procedures [http://man.ac.uk/04Y6Bo] or contact uml.scholarlycommunications@manchester.ac.uk providing relevant details, so we can investigate your claim.

\section{OPEN ACCESS}




\section{UNIVERSITY OF LEEDS}

This is a repository copy of 'Bound hand and foot and handed over to the caste Hindus': Ambedkar, untouchability and the Politics of Partition.

White Rose Research Online URL for this paper:

http://eprints.whiterose.ac.uk/123470/

Version: Accepted Version

\section{Article:}

Chairez-Garza, JF (2018) 'Bound hand and foot and handed over to the caste Hindus': Ambedkar, untouchability and the Politics of Partition. Indian Economic and Social History Review, 55 (1). pp. 1-28. ISSN 0019-4646

https://doi.org/10.1177/0019464617745925

This is an author produced version of a paper published as Chairez-Garza, JF (2018) 'Bound hand and foot and handed over to the caste Hindus': Ambedkar, untouchability and the Politics of Partition. Indian Economic and Social History Review, 55 (1). pp. 1-28. ISSN 0019-4646. Reprinted by permission of SAGE Publications.

\section{Reuse}

Unless indicated otherwise, fulltext items are protected by copyright with all rights reserved. The copyright exception in section 29 of the Copyright, Designs and Patents Act 1988 allows the making of a single copy solely for the purpose of non-commercial research or private study within the limits of fair dealing. The publisher or other rights-holder may allow further reproduction and re-use of this version - refer to the White Rose Research Online record for this item. Where records identify the publisher as the copyright holder, users can verify any specific terms of use on the publisher's website.

\section{Takedown}

If you consider content in White Rose Research Online to be in breach of UK law, please notify us by emailing eprints@whiterose.ac.uk including the URL of the record and the reason for the withdrawal request. 
'Bound hand and foot and handed over to the caste Hindus': Ambedkar, untouchability and the Politics of Partition

\author{
Dr. Jesús Francisco Cháirez-Garza
}

Email address:

i.f.chairez-garza@leeds.ac.uk

Postal Address:

Jesús F. Cháirez-Garza

School of History

University of Leeds

Michael Sadler Building

Leeds, UK

LS2 9JT

Phone Number:

+44 (0)1133439730 


\begin{abstract}
This paper examines B.R. Ambedkar's dramatically shifting politics in the years prior to Partition. In 1940, he supported the creation of Pakistan. In 1946, he joined Winston Churchill in his demands to delay independence. Yet, in 1947, Ambedkar rejected Pakistan and joined the Nehru administration. Traditional narratives explain these changes as part of Ambedkar's political pragmatism. It is believed that such pragmatism, along with Gandhi's good faith, helped Ambedkar to secure a place in Nehru's Cabinet. In contrast, I argue that Ambedkar changed his attitude towards Congress due to the political transformations elicited by Partition. Ambedkar approached Congress as a last resort to maintain a political space for Dalits in independent India. This, however, was unsuccessful. Partition not only saw the birth of two countries but also virtually eliminated the histories of resistance of political minorities that did not fall under the Hindu-Muslim binary, such as Dalits. In the case of Ambedkar, his past as a critic of Gandhi and Congress was erased in favour of the more palatable image of him as the father of the constitution. This essay reconfigures our understanding of Partition by showing how the promise of Pakistan shaped the way we remember Ambedkar.
\end{abstract}

Keywords:

Ambedkar, Partition, Nehru, Churchill, Pakistan, Untouchability 


\section{'Bound hand and foot and handed over to the caste Hindus': Ambedkar, untouchability and the Politics of Partition ${ }^{1}$}

This paper examines the political mobilization of B.R. Ambedkar, the Dalit (Untouchable) politician and intellectual, in the years prior to the Partition of India in $1947 .{ }^{2}$ During this period, Ambedkar's politics shifted dramatically. In 1940, he supported the creation of Pakistan. From 1942 to 1946, he served as the Minister of Labour in the Viceroy's Executive Council. In 1946, he started a series of satyagrahas (passive resistance) across India and joined Winston Churchill in his demands to delay independence. Yet, in 1947 Ambedkar rejected Pakistan, joined the Nehru administration, and eventually became the Chairman of the Constitution Drafting Committee. Traditional narratives have explained these changes as part of Ambedkar's political pragmatism. It is commonly believed that such pragmatism, in combination with the good faith of Nehru and Gandhi, helped Ambedkar secure a place in Nehru's Cabinet. Academics like S.M. Gaikwad, M.S. Gore and Christophe Jaffrelot argue that Nehru offered Ambedkar a ministerial office 'doubtless under Gandhi's pressure' ${ }^{3}$ I do not subscribe to this view. Instead, I argue that Ambedkar changed his attitude towards Congress due to the transformation of the Indian and international political landscape elicited by the developments of Partition and World War II. Ambedkar reached out to Congress as a last resort to maintain a political and historical space for Dalits in independent India. This attempt was unsuccessful. By highlighting the links between Ambedkar, untouchability and Partition, this paper sheds light on how 1947 not only saw the birth of two countries but also virtually eliminated the histories of resistance of other political groups in India and Pakistan such as Dalits. In the case of Ambedkar, his past as a critic of Gandhi and Congress was erased in favour of a more palatable image of him as the father of the constitution. In short, 
this essay offers a reconfiguration of our understanding of Partition by showing how the promise of Pakistan shaped in great measure the way we remember Ambedkar.

On a theoretical and comparative level, this article speaks to the way decolonisation has shaped the history and the politics of minorities in multicultural countries. The article does this in two ways. First, the focus on Ambedkar and Dalit politics at the brink of Partition shows the British abandonment of the minorities they claimed to protect during their presence in India. On the one hand, this unveils the tensions of liberal civilizational discourses in which the rights of cultural and political minorities were important as long as they served a purpose. In this case, Ambedkar and Dalits were useful to the British to counter the Congress claims of being the most representative political organisation in the country. On the other hand, Dalits and other minority groups saw in the colonial state a way to address their social grievances and access political power, even if only in a limited manner. Second, the process of decolonisation in South Asia, combined with the construction of national histories, has often forgotten alternatives narratives of Partition. The birth of 'master narratives' both in Pakistan and in India have marginalised histories that do not fit neatly in the trajectory towards independence but are deeply connected to this process. I highlight this by recovering the often forgotten episode in the years prior to Partition in which unlikely allies, such as Ambedkar and Churchill, approached international organisations to defend their interests.

To look at the problem of untouchability under the light of Partition is paramount. Dwaipayan Sen has shown how the links between Partition, caste and untouchability have been deeply understudied. ${ }^{4}$ After seventy years, the historical knowledge of Dalit experiences in the years prior to Partition and its aftermath is very limited. ${ }^{5}$ This gap may be explained in two ways. First, Partition has often been seen as a Hindu-Muslim (and sometimes Sikh) conflict mainly restricted to specific regions of India. Studies covering this topic have privileged histories regarding the formation of two new countries. Similarly, there also has 
been an emphasis on how the violence associated with Partition shaped life in India and Pakistan. This skewed vision has occluded the experiences of other religious and political groups that do not fit nicely into the Hindu-Muslim binary. ${ }^{6}$ As noted by Urvashi Butalia, there is still plenty to be heard about Partition and the way it affected women, Christians and Dalits among others. ${ }^{7}$ Second, on a political level, conventional views on Partition have focused on the work of the British, Congress and the Muslim League. Under such works, the struggle against untouchability does not seem to have been affected by 1947 . These histories of 'high politics' have centred on people like Jinnah, Nehru and Mountbatten. This has left other key personalities, such as Ambedkar, on the side-lines of history. Furthermore, the nationalist histories that came after 1947 have placed Congress as a party capable of speaking for India as a whole. Thus, the dissent groups like Dalits have been replaced by narratives of inclusion and diversity emerging under a new nation.

In recent years, however, the absence of caste in Partition studies has been addressed more directly by people like Gyanendra Pandey, Ravinder Kaur, Ramnarayan Rawat and Sekhar Bandyopadhyay. Pandey, for instance, has documented the violent experiences of Punjabi Dalits during Partition. In doing so, he has also challenged the common belief that Untouchable communities were not affected by the developments of $1947 .{ }^{8}$ On her part, Ravider Kaur has shown how a 'master narrative' of Partition, often reflecting upper-caste views, has excluded the experiences of displacement felt by Dalit communities. ${ }^{9}$ Finally, the work of Rawat has offered us an interesting account of the mobilisation of Dalit political groups against Congress in Uttar Pradesh from 1946-1948. ${ }^{10}$ He argues that these grassroots politics challenge historical narratives sustaining that, after 1946, most of the Untouchable population had been integrated to the nationalist movement led by Congress. ${ }^{11}$ All of these works have invaluable merit. They have provided new missing perspectives of a crucial historical event in India. However, these studies restrict their interest to Northern India. They 
also do not say much about the international and larger political implications of Partition towards Dalit politics. To complement rather than to challenge these studies, this article focuses on Ambedkar's efforts to secure political safeguards before the British left India. This article shows that the connections between untouchability and Partition were not restricted to specific regions of India but had international resonance.

The work of Bandyopadhyay deserves a space of its own. Bandyopadhyay has produced one of the most complete analysis on the relationship between Dalit politics and the transfer of power in India. Looking roughly at the same period covered by this article, Bandyopadhyay argues that Ambedkar's 'electoral debacle' and continuous changes in politics during the pre-Partition years were due to a 'crisis'. ${ }^{12}$ Bandyopadhyay attributes this crisis to three main reasons. First, Bandyopadhyay argues that one of 'the main thrust of the transfer of power was a process to depoliticize caste and push it into the social and religious domain'. ${ }^{13}$ In his view, this process greatly affected Dalits and all other political minorities that were not politically defined by their religion as they would fall now under the 'General' constituency category. In other words, these groups were losing their specific political power once defended by the colonial administration. While some of this is true, the way Bandyopadhyay arrives to his conclusion is peculiar. That the British decided to withdraw any type of political support to Dalit groups was hardly an effort to 'depoliticize' caste. On the contrary, the transfer of power was an acknowledgement of Congress' political views on religion and the status quo of caste. There are plenty examples of this ranging from Ambedkar's resignation from Nehru's government due to the debates surrounding the Hindu Code Bill, to the refusal of the Indian Government of giving any sort of reservations to Buddhist converts until the 1990s. In other words, the transfer of power had nothing to do with a 'depoliticization' of caste. It was just an acceptance of the normative view of caste. 
Second, Bandyopadhyay also attributes the Dalit political crisis during the transfer of power to 'the dismal state of their organizational network' and Ambedkar's detachment from 'the ground realities of dalit politics' ${ }^{14}$ To prove his argument, Bandyopadhyay uses the election results of 1946 in which the Scheduled Castes Federation (SCF) was only able to elect two candidates out of 151 reserved seats. He also notes that even in the primary elections, where only a Dalit electorate was allowed to participate, the SCF did poorly as well. For Bandyopadhyay, this electoral defeat was mainly due to the "near total lack of organisation' of Ambedkar and his lieutenants. Once again, there is some truth in such conclusion. However, as many academics have shown, the Poona Pact was highly detrimental to Dalit politicians outside Congress. Due to the Poona Pact, the idea of separate electorates was scrapped. This meant that the general constituency was able to vote even for the candidatures reserved for Dalits. The claim that there was a lack of organisation is also problematic. Being disorganised is very different from being outgunned. It is very unfair and somewhat naïve, to compare Congress' financial and political machinery, including the press, against that of the SCF. Ambedkar's electoral failure was not due to a lack of organisation but to an uneven playing field.

Finally, Bandyopadhyay considers that the Dalit political crisis of the 1940s was connected to the rise of nationalism and the lack of political imagination of Ambedkar to appeal to a wider audience. Bandyopadhyay claims that Ambedkar's criticism of Congress kept him from opposing colonialism. This was out of touch with 'the dominant mood of the people and all other political parties...to achieve and enjoy the long-awaited freedom' ${ }^{15} \mathrm{He}$ concludes that 'the result of this was the elimination of what Ambedkar imagined to be a viable third force in the troubled Indian politics of the 1940s'. But what Bandyopadhyay reads as a failure on Ambedkar's part to appeal to the general population, one could also read it as the workings of the prejudices against Dalits in a caste society. Furthermore, to claim 
that at this time the majority of the Indian population was ready to 'enjoy the long-awaited freedom' is to reinscribe the 'master narratives' in which the birth of India as an independent nation takes precedence over other alternative historical accounts. Bandyopadhyay's work raises important questions about the relationship between caste and partition. This article is in conversation with his work rather than a refutation of it.

The article has seven sections. First, I highlight the connections between Dalit and Muslim politics throughout the twentieth century. I show how these groups, as 'minorities', shared a political space and saw themselves as allies. The second section addresses how the Lahore Resolution affected Ambedkar's relation with Jinnah. I offer an account on how the Cripps and the Cabinet missions marginalised Ambedkar from the politics related to the transfer of power. The third section deals with Ambedkar's response to the abandonment by his Muslim and British allies. This response came in a series of satyagrahas throughout the country. The fourth segment deals with Ambedkar's demands for separate settlements for his followers. He saw in this demand a way to avoid caste discrimination in a country where Dalits would be a perpetual minority. The fifth section covers Ambedkar's efforts to place untouchability as an international problem. New evidence is presented on Ambedkar's journey to England to meet with Churchill and his plans to present a complaint to the United Nations (UN). This is followed with an alternative interpretation on the reasons Ambedkar decided to join the Nehru government. Finally, I offer some concluding remarks.

\section{Jinnah and Untouchability}

The extensive political connections between Muslims and Dalits have received little attention from scholars. ${ }^{16}$ The political history between the different communities in India was never two-sided (whether it was Hindu-Muslim, British-Hindus or Dalits-Hindus) but was largely multilateral. Each community made political calculations affecting all of the different political organisations in the country. This was the case with Muslims and Dalits too. For 
instance, one of the first challenges to Dalits being classified as Hindus in the colonial census came from the Aga Khan. This ignited a movement for the conversion and purification of Dalits to either Islam, Christianity or Hinduism. ${ }^{17}$ When Choudhry Rahmat Ali imagined the cartography of Pakistan, he assigned a space in the Gangetic heartland named 'Akhootistan' or Land of the Achhuts/Dalits. ${ }^{18}$ During the 1939 'Day of Deliverance', Ambedkar and Jinnah joined hands to celebrate the resignation of Congress leaders from colonial governmental offices. The late colonial politics of Muslims and Dalits were interconnected. They shared a political space and for some time, they believed that together they could achieve common purposes. However, the political changes elicited by the start of World War II transformed this relationship.

The Lahore Resolution of 1940, seen as the official call for Pakistan, complicated the politics between Muslim and Dalits. At the time, serving as the head of the Independent Labour Party of India, Ambedkar wrote a report spelling the party's attitude towards the resolution. This report was published initially under the title Thoughts on Pakistan (1940), and later as Pakistan or the Partition of India $(1945,1946) .{ }^{19}$ The first edition of the book was supportive of Pakistan because it went along the principles of self-determination. Ambedkar explained that Muslims and Hindus had different cultures and their histories were often incompatible. Thus, the development of a 'consciousness of kind', necessary for a strong nation was very unlikely. Yet, Ambedkar did not see the creation of Pakistan as a definitive answer to the future of the subcontinent. He suggested that the possibility of Pakistan re-joining Hindustan should be kept open. Ambedkar argued that after a period of ten years, a plebiscite could be arranged to survey what the people wanted to do. He was sure that after a trial, if the Muslims decided to come back, India would have a better chance of survival. Keeping an open channel between the two states, through an international board of 
arbitration, would also ensure the security and safety of all of the existing minorities left behind in the new created countries.

It would be much better that the Musalmans should have the experience of Pakistan. A union after an experience of Pakistan is bound to be stable and lasting. In case Pakistan comes into existence forthwith, it seems to me necessary that the separation should not altogether be a severance, sharp and complete. It is necessary to maintain live contact between Pakistan and Hindustan so as to prevent any estrangement growing up and preventing the chances of reunion. A Council of India is accordingly provided for in the Act. It cannot be mistaken for a federation. It is not even a confederation. Its purpose is to do nothing more than to serve as a coupling to link Pakistan to Hindustan until they are united under a single constitution. ${ }^{20}$

Ambedkar was thus supportive of the creation of Pakistan, at least in the first edition of his book. It is important to highlight that despite his support for dividing India, he did not see this as a final solution. This suggests that the future of the political landscape, in the eyes of Ambedkar, was still to be defined.

This vision did not last long. Ambedkar offered a very different view in the second and third edition of his book on Pakistan. He added six more chapters and fourteen appendices. In the new editions, he argued that India should stay together to prevent a civil war against Muslims and to discourage attacks by foreign powers. This change in Ambedkar's attitude had to do with the changing political climate of the 1940s. In particular, Ambedkar feared that his movement would lose relevance by the implementation of the Cripps Mission and Jinnah's demands for 'parity' of representation between Muslims and Hindus.

\section{Cripps, Cabinet and the Fall Out with Jinnah}

With the Japanese menace in Singapore, Malaya, and the bombing of Pearl Harbor, the Cripps Mission tried to ensure the loyalty of the main political communities of India to the British during WWII. ${ }^{21}$ After consulting different political groups, Cripps offered the creation 
of a constituent assembly, dominion status to the provinces of India and elections after the war. $^{22}$ These proposals failed in the end but they are quite significant to understand Ambedkar's politics in the following years. The proposals revealed the hand of both Jinnah and the British towards Dalits. Ambedkar was weary of Jinnah's demands for two reasons. First, Pakistan would mean the loss of a political ally against a Hindu majority. Second, Jinnah demanded fifty per cent of any type of political representation in the country for Muslims if Pakistan was not conceded. Ambedkar called this demand 'a monstrous thing' as it effectively eliminated Dalits as an important political entity. ${ }^{23}$ In other words, Jinnah was envisioning a future where Muslims did not have to share their political space with other minorities.

The British, on the other hand, were choosing their battles carefully in India. After the setbacks experienced in Malaya, Churchill's government tried to strengthen their relationship with Congress and the Muslim League. This left other minorities stranded. Ambedkar described the Cripps proposals as a sudden 'volte face' in which Dalits were being forgotten despite their loyalty throughout the years. While addressing a conference of his followers in 1942, he argued that the 'Constituent Assembly [was] intended to win over the Congress, while the proposal for Pakistan [was] designed to win over the Muslim League'. Ambedkar claimed that Dalits were 'bound hand and foot and handed over to the Caste Hindus. They [the British] offer them nothing, stone instead of bread'.${ }^{24}$ In particular, Ambedkar wanted to ensure the full representation of Dalits by establishing reservations and separate electorates before the British left India. In short, the Cripps Mission made clear that the Muslim League and the British were not Ambedkar's political allies. Instead, he discovered that they were ready to sacrifice Dalits to advance their own political interests. Such disavowal of Dalit politics was well in advance of the elections of 1946, in which Ambedkar's party would do very poorly. 
Despite the political disillusionment with Jinnah after Cripps, Ambedkar tried one last time to show him how staying in India could benefit both of their causes. Just as the Simla Conference of 1945 was preparing to meet, Ambedkar published Communal Deadlock and the Way to Solve it. ${ }^{25}$ This text aimed to show Jinnah how a fair political system in a united India could look like. Ambedkar's key argument was that political majorities in India should disappear both in practice and in theory. In this scheme, a community could not have more than 40 percent of the actual representation in any of the different legislatures. This would ban the perpetual ruling of majorities throughout the country. That is, in order to approve any type of legislation, the majority would have to make an alliance with at least one of the minorities. In the same way, if all the minorities joined together, they would be able to confront the politics of the largest community. This meant that the political system would change constantly and communal views would eventually disappear in favour of shared political objectives. This arrangement would also give Dalits a privileged position in Indian politics as they were the third largest community in the country. Thus, Ambedkar envisioned Dalits as a political force that could shift their alliances according to specific circumstances. This text constructs an alternative imagination of the Indian political space. Ambedkar's proposal of eliminating political majorities would also appeal to other 'multicultural nations' in which a dominant group monopolises politics at the expense of other minorities. However, the small caveat in Ambedkar's plan was that Muslims and Jinnah needed to accept living as a minority in a Hindu country.

As expected, Ambedkar's proposals were not welcomed. Congress rejected his plan as they didn't want to renounce to their majority status. ${ }^{26}$ On his part, Jinnah was asking for parity of representation for Muslims vis-à-vis Hindus. This was a blow to the other minorities that may have seen in Muslims a political ally. After this, Ambedkar lost all of his faith in reaching an agreement with the Muslim League and warned his followers not to trust 
Muslims when it came to politics. In November 1947, Ambedkar reflected about his interaction with Jinnah: 'The Muslims wanted the support of the Scheduled Castes but they never gave their support to the Scheduled Castes. Mr. Jinnah was all the time playing a double game. He was very insistent that the Scheduled Castes were a separate entity when it suited him but, when it did not suit him he insisted with equal emphasis that they were Hindus' ${ }^{27}$ This reflects a significant change of attitude on Ambedkar's part towards Jinnah and the creation of Pakistan.

The political situation worsened for Ambedkar as the establishment of the Cabinet Mission of 1946 was announced. ${ }^{28}$ The Mission made it clear that it was not their intention to recognise Dalits as one of the communities to be consulted in the transfer of power. Ambedkar considered this a betrayal. Not only did the Cabinet Mission fail to provide constitutional safeguards for Dalits, but by not recognising them as a separate political entity in the Constituent Assembly they were marking them as Hindus. This contradicted the British policies towards Dalits that had been in place for more than twenty years. Furthermore, Ambedkar pointed out that giving political recognition only to Hindus, Muslims and Sikhs was to treat Partition as a regional issue rather than as a problem with national and international implications. The Cabinet Mission, however, did not give much importance to Ambedkar's criticism. They argued that the election results of 1946, in which the Scheduled Castes Federation did miserably and even Ambedkar failed to be elected, showed that it was Congress who had the real support of Dalits. ${ }^{29}$ As a result, Ambedkar was forced to look for different sources of support for his cause, in this case outside of India.

In his last attempt to secure the rights of Dalits before the British left, Ambedkar deployed a three level strategy. First, he launched a series of satyagrahas around the country, with Poona and Lucknow as the centre points. The satyagrahas were implemented to abrogate the Poona Pact of 1932, ${ }^{30}$ which effectively banned separate electorates for Dalits. 
The protests also demanded evidence that Congress was committed to the protection of Dalits. ${ }^{31}$ Second, Ambedkar demanded the creation of separate settlements to relocate Dalits within India as a way to escape caste oppression. ${ }^{32}$ Third, Ambedkar tried to secure political representation for his followers by framing untouchability as an international problem. On the one hand, he threatened the British by suggesting that he would make a formal complaint to the UN about the injustices committed against Dalits. On the other, Ambedkar contacted Winston Churchill to delay independence until some safeguards for his people were secured. Together, the different strategies used by Ambedkar show how Partition elicited a series of changes at a national and international level in the politics around untouchability. These strategies also show that Ambedkar's movement was organised and that they were able to pressure the government in several ways. Finally, that Ambedkar was willing to explore every possible political alliance at this time, except compromising with Congress, says a lot about the broadness of his political imagination.

\section{Satyagrahas, Separate Electorates and the Poona Pact}

On 15 July 1946, six members of the SCF entered the Council Hall compound in Poona to protest the Cabinet Mission's proposal for India. They carried black flags and shouted slogans of 'Down with British Imperialism'; 'Down with Congress'; and 'Scrap the Poona Pact'. ${ }^{33}$ After this group was arrested, two more batches followed. The first one was composed of eight women. In the second batch there were six men. These protesters were also arrested at the entrance of the compound wall. Simultaneously to the arrests, a procession of Dalits began from the 'Satyagraha' camp at Babajan Chawk. It was headed by P.N. Rajbhoj and R.R. Bhole, who were Ambedkar's lieutenants in Poona. Over one hundred police officers, armed with lathis, stopped the march before it got near Council Hall. A few days earlier, the District Magistrate had prohibited any type of meetings or protest 'along the area of half a mile from Council Hall and the Secretariat'. ${ }^{34}$ In response, the satyagrahis 
squatted on the ground shouting slogans in favour of Ambedkar and the SCF. They returned to their camp after two hours. There, Rajbhoj addressed the protesters and told them that this was the beginning of a countrywide movement for the freedom of Dalits. ${ }^{35}$

A few days later, Ambedkar explained the purpose of the satyagraha in an interview to the Bombay Chronicle. He demanded a 'blue print' of how Dalits were to be treated by Congress after the British left India. He claimed that the demonstration at Poona was only the beginning. It was not to be taken lightly as he had 'not yet shown [his] full teeth'. Ambedkar also warned that the struggle for Dalit rights would 'grow grimmer and fiercer day by day'. In a challenging manner, and linking once again Muslims and Dalits, Ambedkar argued that his community could nullify the existence of Congress by converting to Islam. Personally, he mentioned, this would benefit him too as Jinnah 'might nominate [him] as a Muslim member to the Executive Council'. However, softening his tone, Ambedkar clarified that he did not want to resort to such measures as his intention were to 'save the Congress from total degradation'. ${ }^{36}$ This interview is quite interesting. It shows us that Ambedkar was still using the Muslim League as a way to advance his argument despite that his relationship with Jinnah had broken down. Ambedkar's statement about saving Congress from degradation also suggests that a compromise with such party in the future was very likely.

Another important element of the satyagrahas was the demand for the abrogation of the Poona Pact. This request was directed mainly at the colonial government. Ambedkar blamed the Poona Pact for the loss of the SCF in the elections of 1945-6. The Poona Pact has a long history. It was an offshoot of the Communal Award of 1932. Ramsay MacDonald, the acting Prime Minister of Britain at the time, recognised Dalits as an independent political minority through the Communal Award. The Award established a set number of political seats that could only be contested and elected by Dalits. In other words, separate electorates were set in place. Thus, Dalits were being differentiated from the general constituency largely 
composed by Hindus. The Communal Award did not sit well with Gandhi who thought that separate electorates were going to divide and destroy Hinduism. In protest, on 20 September 1932, Gandhi started a 'fast unto death'. ${ }^{37}$

The colonial government designed the mandate of separate electorates. Nonetheless, much of the pressure regarding Gandhi's fast fell on Ambedkar. The latter was largely seen by public opinion as the main advocate of special political representation for Dalits. The colonial government claimed that the only way to change their decision was if an agreement was reached between the feuding parties. Such move left Ambedkar with few options to reach a good bargain. On the one hand, the British gave Ambedkar the cold shoulder, fearing that Gandhi, incarcerated in Yerwada jail, would die under their care. On the other, Ambedkar had to deal mostly on his own with the full political force of Congress and with the anger of the general public who held him responsible for the Gandhi's life.

After four days of intense negotiations, Ambedkar and Gandhi reached an arrangement. The result was the Poona Pact. ${ }^{38}$ This agreement increased the number of reserved seats in provincial legislatures for the Depressed Classes. While the Communal Award gave 78 seats, the new treaty awarded 148. This increase in seats may seem like a significant gain, but it wasn't. The main feature of the Poona Pact was the elimination of separate electorates. Instead, the Pact envisioned a two-tier election system for Untouchable candidates. ${ }^{39}$ During the primary elections, the different political parties nominated the candidates for the reserved seats. At this stage, only members of the Scheduled Castes were eligible to vote. The top four candidates would then move on to the second stage, the general elections. Here there were no restrictions for voters. It is not hard to see Ambedkar's problem with this. He argued that the electoral system was rigged against Dalits as the candidates who topped the polls in the primaries would then fail to be elected by the general constituency. He attributed this to the small number of voters belonging to the Scheduled Castes. Ambedkar 
also believed that his party did not have enough resources to compete against Congress candidates for an extended period of time.

When the Cabinet Mission announced that they were basing the distribution of political seats for Dalits on the results of the 1945-6 elections, Ambedkar wrote a lengthy letter to the British Prime Minister Clement Attlee. He protested that in the primary elections the candidates of the SCF had done far better than the Congress counterpart. He accused Congress candidates as being mere 'tools' that did not represent the interests of Dalits.

The Primary election is an election in which only the Scheduled Castes voters are entitled to vote for the Scheduled Castes candidates contesting a seat reserved for them, while in the Final election the Hindu voters are also entitled to vote for a Scheduled Castes. The Hindu voters being overwhelming, they are able to elect that Scheduled Castes candidate who is their tool. This explains how the Congress Scheduled Castes candidates, who all were at the bottom in the Primary election, came to the top in the final election. ${ }^{40}$

Attlee's reply dismissed Ambedkar's claims. Attlee accepted that the Poona Pact may have been unjust but he did not see enough reasons to change it. Ambedkar's failure to be elected from Bombay did not help his claim of being the foremost representative of Dalits. As a result, Attlee refused to make any statement in support of Ambedkar as this would 'inevitably be interpreted as an attempt to interfere with the [Constitutent] Assembly's freedom and as such would be likely to cause serious resentment'. ${ }^{41}$ Attlee's reply was surprising. Not only was he withdrawing the British support to Dalits vis-à-vis Congress, he was also adopting the old Gandhian argument that Ambedkar was only a marginal/regional leader. Despite this, Ambedkar carried on pressuring the British through satyagrahas.

The satyagrahas continued intermittently from July 1946 to April 1947. As Ramnarayan Rawat has shown, the protest proved that the Federation had some political force in Congress enclaves. ${ }^{42}$ The most important protests were held in Poona, Lucknow and 
Kanpur. While he was not very involved in the satyagrahas, the slogans and demands in all of these places were in line with Ambedkar's political views. For instance, in Nagpur, over 10,000 people of the SCF, including over five hundred women, shouted 'Boycott Constituent Assembly'; 'Down with Congress ministry'; 'Boycott Harijan M.L.A's' and 'Revoke the Poona Pact'. As we have seen, all of these points were commonly addressed by Ambedkar at this time, both in his interviews and in his writings.

At the same time, Ambedkar's lieutenants were framing the injustices committed against Dalits as an international problem. To do this, the leaders of the SCF often compared their situation in India with the grievances of other excluded communities across the world. This is clear from the daily reports of the satyagrahas that took place in April 1947 in U.P. The reports, published by the Madras journal Jai Bheem, usually covered the highlights of the day, the number of people arrested and a denunciation of the events that were not covered by the mainstream press. This documentation reveals a big input of women and children in the satyagrahas. They recorded that a total of 1387 protestors had been arrested. The reports accused the 'Caste Hindu' press in Lucknow of omitting the violence committed against Dalits, particularly female protesters. They argue that 'the ladies were insulted', their bangles 'were broken' and that 'fists were used to oust the ladies' by the police from the Assembly chamber. ${ }^{43}$ Furthermore, the reports often quoted passages from speeches made by the main leaders of the movement such as P.N. Rajbhoj who had travelled from Poona to join the cause. Rajbhoj speeches reflected Ambedkar's main tenets. They urged Dalits to be 'united and strong of one mind and one voice... and to fight together under one banner' ${ }^{44}$ Rajbhoj claimed that their struggle was to 'have equal human rights in political, social and economic India'. ${ }^{45}$ He gave the satyagraha an international dimension by comparing untouchability with the experiences of African-Americans and Jews. In his words: 'I may say that the treatment of the Australian Bushman by the colonisers, that of the Negroes by the Ku Klux 
Klan and of the Jews by the Nazis is less heinous than the sufferings of the Scheduled Castes who were subjected to in the name of religion, caste and the like by the Hindus. It is nothing but a slow poisoning to us'. ${ }^{46}$ These reports show us that through their own press, the Dalit movement was reaching people far beyond the places of the satyagrahas. They also show that certain political guidelines were being spread by the SCF to consolidate their protest as a united Pan-Indian movement. Finally, the account provided by Jai Bheem also illustrates that Ambedkar's followers adopted the language of internationalism and human rights that was in vogue at the time.

The satyagrahas ended abruptly when P.N. Rajbhoj was arrested in April 1947. He was convicted and sentenced to six months imprisonment for defying the U.P. District Magistrate's ban on processions and causing apprehension of breach of peace. ${ }^{47}$ While these satyagrahas are largely a forgotten episode in Indian history, they were highly organised political protests. In the end, these satyagrahas allowed Ambedkar to put some pressure on the British and Congress. This would eventually help him secure a place in Nehru's new government. Of course, as stated before, the satyagrahas were part of a larger plan to secure safeguards for Dalits. Another element of this strategy was Ambedkar's demand for separate settlements for his people.

\section{Ambedkar and Separate Settlements}

The campaign for separate settlements came along with other demands against the Cabinet Mission's proposal. The main reason behind it came from Ambedkar's characterization of Indian villages as oppressive and as bastions of untouchability. ${ }^{48}$ This was not surprising. Ambedkar had been a long critic of the Indian village. Such criticism dates back to the 1920s when Ambedkar participated as a Dalit representative in the Simon Commission and in the Starte Committee. On both occasions, he argued that the village functioned as an oppressive mechanism for Dalits. To prevent any type of revolt, the close knitted structure of the village 
permitted the implementation of social boycott against Dalits. ${ }^{49}$ This line of thought was reflected in a memorandum addressed to the Cabinet Mission in April $1946 .{ }^{50}$ In it, Ambedkar highlighted three key points to be granted Dalits before India's independence. The first two points were familiar. He wanted a provision for separate electorates and adequate representation in the legislature, the executive and in the services. Third, Ambedkar demanded separate settlements as 'the Scheduled Castes in every village all over India are in fact the slaves of the Hindus'. ${ }^{51}$ Ambedkar wanted a constitutional provision that ensured the establishments of these settlements. Under such legislation, the Central Government would create and financially support a Settlement Commission. These two bodies would be constitutionally obligated to hand over cultivable, but unoccupied, land to Dalits. They would also have to transfer this group to the new settlements. Ambedkar proposed that the new constitution should finance the Settlement Commission with at least five crores rupees per annum to purchase new land from private owners whenever necessary. ${ }^{52}$

While his demands to the Cabinet Mission were not very effective, Ambedkar did not drop this subject altogether. The call for a separate settlement was also present in the satyagrahas discussed above. For instance, on 12 September 1946, 243 members of the SCF of the Central Provinces were arrested in Nagpur. When confronted by the officers preparing their arrest sheet, the protestor gave an interesting answer. They 'stated that "Jai Bheem" was their name, their caste was "Scheduled Castes Federation" and "Dalitsthan" was their residence'. ${ }^{53}$ That the satyagrahis were aware of the struggle for separate settlements shows that there was some communication between Ambedkar and his lieutenants. This also reveals that Ambedkar was not working on his own to change the political panorama for Dalits. Finally, such demand highlights the spatial aspects of untouchability introduced by Ambedkar through his writings. 
When it was clear that a Constituent Assembly was going to be formed, Ambedkar revived his demands for separate settlements in his 1947 States and Minorities. In this piece, Ambedkar demanded separate settlements mainly for economic reasons. He argued that in most villages, Dalits were landless labourers dependent on the jobs and wage conditions set by their Hindu employers. This was unfair as Dalits did not have anything to bargain to protect their interests. Equally, the power structures of the village also prevented Dalits from engaging in other trade or occupations, as other Hindus would not deal with them. That is, Dalits would be unable to earn a living as long 'as they live in a Ghetto as a dependent part of the Hindu village'. ${ }^{54}$ Ambedkar described such economic conditions as part of a Hindu code which was 'incompatible with the dignity and sanctity of human life'. He explained that these were not isolated incidents but were part of a perpetual war 'going on every day in every village between the Hindus and the Untouchables'. Ambedkar argued that these mistreatments went often unreported as the Hindu Press did not want to injure 'the cause of their freedom in the eyes of the world'. Apart from the support of the press, Hindus also had the Police and the Magistrates on their side. These loved their caste 'more than their duty'. Ambedkar contended that this was another reason why Dalits could never succeed in the village. In short, if Dalits were not given separate settlements, they were being condemned to live in 'perpetual slavery'. 55

It is important to highlight that in States and Minorities, Ambedkar adjusted his demands to an international audience. He matched his ideas about the village with a new vocabulary that echoed the times following the end of WWII. For instance, to show the injustices committed towards Dalits, Ambedkar commented that while Hindus lived in the village, Dalits lived in the ghettoes. For him, it was the village that allowed untouchability to exist and prevented Dalits to 'free themselves from the yoke of the Hindus' ${ }^{56}$ Ambedkar elaborated further on this point and claimed that it was the Indian ghetto that provided 'an 
easy method of marking out and identifying the Untouchables'. ${ }^{57}$ Due to these reasons, Ambedkar demanded that the nexus between Dalits and the village be broken. He said that Dalits were already socially separate from the Hindus. Therefore, Dalits 'should be made separate geographically and territorially also, and be settled into separate villages exclusively of Untouchables in which the distinction of the high and the low and of Touchable and Untouchable will find no place' ${ }^{58}$ This new way of posing the question of separate settlements not only resonated with the Jewish experience during WWII but also with the Zionist movement. Furthermore, it also shows that Ambedkar wanted to place untouchability as an international matter by comparing his demand for separate settlements with similar claims put forward by other oppressed communities in the world.

\section{Churchill and Untouchability as an International Problem}

In 1946 and early 1947, Ambedkar approached the UN and Winston Churchill. In his mind, drawing the attention of the international community would buy him some time to ensure the political protection of Dalits before independence. Today, Ambedkar's attempt to use the UN and his alliance with Churchill are largely unknown. Nonetheless, at the time it was taken very seriously.

Ambedkar's idea to take the case of Dalits to the United Nations was not a coincidence. It was a timely and careful plan that responded to the turbulent period at the end of WWII. As a recognition of its efforts during the War, India was given an independent seat in the United Nations and was considered a founding member of the organisation in 1945. While it was still a British colony, India took advantage of its membership to present concerns to the General Assembly in the very first session of $1946 .{ }^{59}$ At this time, India made a formal complaint against South Africa for discriminating against Indian nationals. The core of the problem was that Jan Smuts' administration planned to pass the South African Asiatic Land Tenure and Indian Representation Act. This bill restricted the purchase of land to Indian 
nationals to specific areas. ${ }^{60}$ The Indian representation to the UN claimed that the 'Ghetto Law' was a contradiction to the human rights of the Indian minority. They highlighted that the Act contradicted the principles defended by Jan Smuts in the preamble of the UN Charter in $1945 .{ }^{61}$ On his part, Jan Smuts claimed that the bill was a domestic matter in which the UN had no right to interfere. Despite Smuts' reluctance, the UN demanded an end of discrimination and a called for bilateral talks. When Smuts refused to abolish the act, India suspended the commercial agreements it had with South Africa.

Ambedkar, always with an eye on international affairs, saw the inherent contradiction in India's appeal to the UN. India was making a claim in defence for the rights of the Indian minority in South Africa, while refusing to grant any importance to the claims of Dalits in their own country. As a result, Ambedkar began to organise a delegation to present the grievances of the Schedules Castes to the United Nations. He not only informed the foreign press of his plans, but also contacted political leaders like WEB Du Bois. In a brief exchange, Ambedkar asked Du Bois for advice on how The National Negro Congress filled a petition to present their case to the UN. ${ }^{62}$ Ambedkar's attempt to elevate his cause to an international level also gained attention from South Africa. Jan Smuts himself brought up the question of untouchability when Maharaj Singh, Indian delegate to the UN and former Governor or Bombay, accused South Africa of racial discrimination. Smuts claimed that India should be the last country to throw stones at others when it came to class distinctions and social bias. He said that this inequity was the 'very basis and pattern of Indian society'. Finally, Smuts compared the situation of Dalits and Indians in South Africa by questioning Singh: 'Has the delegate for India forgotten the 50,000,000 depressed classes, with all the social ostracism and humiliation that they have to endure- a phenomenon unknown in South Africa and in the rest of the world?'.63 
Ambedkar's intention to go to the UN was taken more seriously after Smuts' comments. The British Foreign Office opened a file to follow the complaints of the SCF to the United Nations. The British were worried that Ambedkar could hurt their fragile relationship with India. They were worried that with Smuts on his side, Ambedkar could introduce a motion to present his case to the UN. ${ }^{64}$ Thinking ahead of time, the British modelled a reply to obstruct Ambedkar's future demands. In a surprising shift of attitude, the Foreign Office constructed their argument against Ambedkar on the same basis as Congress. In fact, the British took a reply written by Rajagopalachari, the conservative Congressman, as a model to dismiss Ambedkar's claims. ${ }^{65}$ The Foreign Office argued that in contrast to the South African case, the question of untouchability was not legally sanctioned. That is, untouchability was a religious and a social issue, rather than legal or political. The British also claimed that Dalits were not even a proper minority. This was the position defended by Gandhi and Congress, who saw Dalits as an integral part of the Hindu community. ${ }^{66}$ The recognition of Dalits as a political community was crucial in this debate. If they failed to gain recognition, the UN had no grounds to intervene as the problem would be considered a national matter. ${ }^{67}$ It goes without saying that this was a complete reversal of the policies the British had defended since 1919 when Dalits were given special political representation. In the end, Ambedkar failed to submit his claims to the UN. He couldn't find enough support within and outside the UN. The international system was more interested in Gandhi's plight for independence than on untouchability. This also shows a broader problematic with organisations such as the UN that tend to ignore narratives of oppression that do not fit with mainstream histories of state-formation and nationality.

Around the same time, Ambedkar approached Churchill seeking further support for his cause. Ambedkar and Churchill had met in 1933 during one of the sessions of the Joint Committee on Indian Constitutional Reforms. Back then, Ambedkar examined Churchill on a 
number of issues including the latter's views on responsible government and granting vote to the masses. They clashed in the second topic as Churchill found adult suffrage 'quite impracticable' ${ }^{68}$ Despite this, Ambedkar contacted Churchill in 1946 after the latter criticised Attlee's announcement of the Cabinet Mission Plan. Churchill argued that his party was willing to give India dominion status under three conditions. First, he claimed that an agreement between the main political parties of India was essential. Second, Churchill wanted to guarantee the future of the princely states. Finally, he required a discharge of obligations towards minorities, particularly Muslims and Dalits. In relation to the case of Dalits, Churchill mentioned that this group could not be abandoned as 'repeated assurances have been given and pledges made by many British Governments, in ancient and in more recent times'. Churchill argued that if these conditions were not fulfilled, Britain should continue to rule India. Otherwise, civil war and bloodshed would follow. ${ }^{69}$ While the intentions of Churchill behind such declaration may not have been sincere, several Indian political organisations and individuals sought his support.

On 17 May 1946, Ambedkar sent a telegram to Churchill condemning the Cabinet Mission's proposal as a 'shameful betrayal of the cause of sixty millions of untouchables' ${ }^{70}$ Ambedkar pointed out that the proposal made no provision for having Dalits in the Constituent Assembly or in the Advisory Committee. He also emphasised that without a treaty in place to ensure the protection of Dalits in the future, they would be handed to the Hindus 'bound hand and foot'. Ambedkar concluded that the future of Dalits 'was very dark' and that they depended on Churchill 'for safeguarding their interest'. ${ }^{71}$

Churchill's reply came swiftly. He assured Ambedkar that the Conservative Party would do their utmost to protect the future of Dalits whose 'melancholy depression by their co-religionists constitutes one of the gravest features in the problem of the Indian subcontinent'. Churchill said they would take a stand on the principles of the American 
Declaration of Independence where 'all men are born free and equal and entitled to life, liberty and the pursuit of happiness'. ${ }^{72}$ Despite the irony of Churchill invoking the American Declaration of Independence to defend the British Empire, they decided to publish their correspondence in the British and Indian press. More cables to Churchill followed from other organisations (usually sympathetic to Ambedkar) denouncing Congress and looking for support for their cause.

The communication between Ambedkar and Churchill continued throughout the year. In July 1946, Ambedkar informed Churchill of his attempts to convince Attlee to change the main provisions of the Cabinet Mission. Ambedkar had three demands for Attlee. First, he wanted Dalits to be recognised as a political minority in their own right. He correctly noted that the Simla Conference had acknowledged this a year before. Yet, the Cabinet Mission adopted the nationalist argument that Dalits were Hindus. This would leave Dalits unprotected and at the mercy of the Hindu majority 'who have reduced them to the status of animals' ${ }^{73}$ Second, Ambedkar demanded that before Attlee's government agreed 'to sign the Treaty for conation of sovereignty', constitutional and political safeguards should be put in place to enable Dalits to 'live free from the fear of the Majority'. ${ }^{74}$ Third, Ambedkar wanted that at least two Dalit representatives were included in the interim government. These two representatives were to be nominated by the Scheduled Castes Federation because Congress politicians did not have the best interest of Dalits in their heart. ${ }^{75}$

Ambedkar's demands to Attlee carried some substance. From 1943 to 1946 there was a big change in the British political attitude towards Dalits. As noted before, the Simla Conference recognised Dalits as a 'distinct and important element in the National life of India' ${ }^{76}$ Not only that, Lord Wavell, the Viceroy of India at the time, resisted Gandhi's criticism stating that the Hindus were being divided by larger political interests. Accordingly, he invited different representatives of the Congress and the Scheduled Castes Federation to 
the conference. The Simla Conference also provided two seats for Dalits, in a Cabinet of fourteen, that were to be nominated by the SCF. In contrast, the Cabinet Mission in their statement of $16^{\text {th }}$ June 1946 did not mention Dalits at all. Equally, the initial scheme of the Cabinet Mission did not provide any seats for Dalits in the Executive Council (although eventually one seat was conceded). Finally, the Cabinet Mission gave Congress the power to nominate the representatives of the Scheduled Castes in the interim government. Ambedkar saw these changes as a 'somersault' designed to 'placate the majority by giving it power to dispose of the minorities as it pleased'. He claimed that the policies sketched by the Cabinet Mission were 'the cruellest wrong that the Mission has done to the Untouchables' as their status as an important political minority was to be destroyed. ${ }^{77}$ Ambedkar feared that the little advancement made by Dalits in politics was going to be lost with the disappearance of colonial protections.

Alongside the satyagraha and the UN delegation, having Churchill as an ally allowed Ambedkar to pressure Congress and the colonial government on several fronts simultaneously. Such actions were not without effect. Since early July 1946, Congressmen like S.K. Patil, and N.M. Joshi approached Ambedkar to arrive to a settlement with him. They also arranged a meeting between Vallabhbhai Patel and Ambedkar. They met on 18 July 1946. In the meeting, Ambedkar insisted on separate electorates but Patel refused to budge. In early September, Patel wrote to Ambedkar once again to continue their negotiations. Ambedkar replied on 14 October. He claimed that he had already adjusted his demands and was not willing to do it anymore. He told Patel that "notwithstanding your disagreement with my proposals for a settlement you should have extended to me an invitation to see you, speaks for your goodness of heart. I am sure it can serve no purpose. I must therefore decline it'. Ambedkar also replied to the criticism he had encountered for approaching other political leaders like Churchill. He mentioned that 'there is really nothing 
wrong and nothing shameful for a leader of one party to approach the leader of another party for a settlement. Like a wandering minstrel Mr. Churchill did go from country to country even to Russia to seek help for his country and I should do the same for the sake of the Scheduled Castes' ${ }^{78}$ Is important to note that despite his failure in the elections of 1946 , Ambedkar was still considered relevant enough to be lured by Patel into the Congress' camp.

Just a few days later, Ambedkar travelled to England to have his voice heard. At his arrival, Ambedkar wrote to Churchill that his visit was 'to explain to important persons in the public life of this country the wrong done to the millions of the Untouchables of India by the proposals of the Cabinet mission'. Ambedkar asked Churchill for an appointment to 'brief [him] further with facts and figures' about the situation of Dalits in India. ${ }^{79}$ Ambedkar met Churchill in his country house in Kent. This was probably to go through Ambedkar's planned statements to the British government. In early November, Ambedkar met around twenty Members of Parliament. R.A. Butler, a seasoned Conservative politician, informed Churchill that the meeting went off without major incidents. However, Butler also noted that after the official encounter, 'the Doctor had rather a grilling from a few Labour M.Ps and some members of the Fabian Society, who tried to prove that he was not the only pebble on the Depressed Classes beach and that other representatives of the Depressed Classes were just as important' ${ }^{80}$ Despite this, Butler finally acknowledged that Ambedkar made a good impression on his critics. After this meeting, Ambedkar returned to India while Churchill convinced Parliament to discuss the plans for the transfer of power in December. In that meeting, Churchill made another speech in favour of Dalits but without much success. In the end, Atlee's government rejected Ambedkar and Churchill's demands. As noted above, Attlee refused to provide safeguards for Dalits by invoking the old Congress argument that Dalits were Hindus; that they were politically irrelevant; and that Hindus had the best intentions to advance the cause of Dalits for the sake of the nation. 
The alliance between Churchill and Ambedkar was not very successful. However, it reveals some of the ways in which the idea of Partition prompted several political realignments at a local and at an international level. As we can see, despite Attlee's remarks about the unimportance of Dalits, Ambedkar found different sources of support both in India and abroad. This speaks of the way in which Ambedkar was also internationally recognised as a Dalit leader despite Congress allegations of the contrary. Finally, his approach to Churchill shows us how concerned Ambedkar was about the possible consequences that Partition could have for Dalits.

\section{Nehru and the Incorporation of Ambedkar}

After being aware of Ambedkar's attempts to establish a political alliance with both Jinnah and Churchill among other people, it is more baffling what came on 15 December 1946. On this date, Ambedkar addressed the newly formed Constituent Assembly of India. He was to comment on the Declaration of Objectives presented by Nehru a few days earlier. In his speech, Nehru declared that India's main goal was to become and independent sovereign republic. ${ }^{81}$ This resolution was received ambiguously. Conservative politicians such as Purushottam Das Tandon and S.P. Mookerjee supported Nehru's views. Other senior figures like M.R. Jayakar and Frank Anthony wanted to postpone the passing due to the absence of the Muslim League to vote or discuss the motion. This led to a heated debate. Each side accused the other of not having the best interest of the nation in mind. At this point, something strange happened. Rajendra Prasad, the President of the Constituent Assembly, called Ambedkar to have his say. Prasad's invitation was quite unusual. Ambedkar was chosen to speak even though there were twenty people before him waiting to give their views. Furthermore, before this time, Ambedkar had not only been trying to forge alliances with the Muslims and the British but had also been publishing direct attacks against the nationalist movement like What Congress and Gandhi Have Done to the Untouchables $(1945,1946){ }^{82}$ 
Ambedkar spoke in a room that was anything but friendly. Everyone expected an antiCongress outburst. Surprisingly, Ambedkar highlighted the opportunity that the Constituent Assembly had to build bridges between the different communities in a united country. He also asked Muslims to drop their demand for Pakistan. Ambedkar's speech wasn't by any means uncritical. In fact, he endorsed Jayakar's initiative to postpone the vote on Nehru's resolution. But Ambedkar's tone and language was not what everyone anticipated. In his speech, Ambedkar noted that the political, social and economic divisions present in India made the country 'a group of warring camps' where he was 'one of the leaders of such a camp'. ${ }^{83}$ Despite this, he said that India's future was that of a united nation:

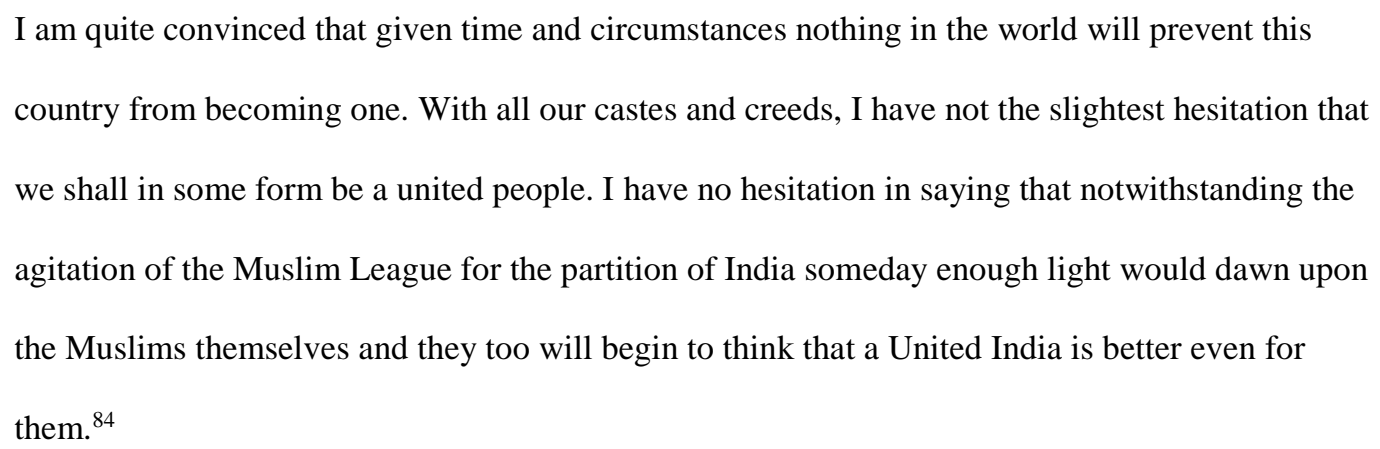

These words were received with cheers and applause. They marked a significant shift in Ambedkar's attitude towards Congress and his views about Pakistan. The nationalist press celebrated this too. The National Standard claimed that '[f]or once, the redoubtable Doctor [Ambedkar] laid aside his role as the Avenging Angel wiping out the bitter memories of centuries old social persecution. For the first time he appeared in the blessed role of a peacemaker' ${ }^{85}$ Rather than trying to become a peacemaker, Ambedkar's adjustment in attitude was due to his isolation in a changing Indian political landscape. With the British hoping for a swift exit from India and with Pakistan appearing clearly in the horizon, Ambedkar realised that he was out of political options other than establishing a new relationship with Congress. 
After his speech, Ambedkar was slowly incorporated into the Nehru government. Of course, this process was already ongoing before Ambedkar's public endorsement of Nehru. In September 1946, Vallabhbhai Patel met with Ambedkar to discuss a possible settlement between Congress and the SCF. ${ }^{86}$ In the same way, important 'Harijan'-Congress leaders urged Ambedkar to join the party. Prithvi Singh Azad was an example of this. Azad, a founding member of the Ghadar Party and who later joined Congress, claimed that 'Dr Ambedkar's place [was] in the Congress...I have every hope Dr. Ambedkar will change his old views and will join the rank and the file of the nationalists Harijans' ${ }^{87}$ Yet, the luring of Ambedkar was not welcomed in all Congress quarters. Some Gandhians were not as pragmatic as Nehru and Patel. They had a longer memory and did not forgive easy. At the same time as the Patel-Ambedkar talks were taking place, two books criticising Ambedkar were published. These were a reply to What Congress and Gandhi Have Done to the Untouchables. In 1945, Gandhi commissioned K. Santhanam and C. Rajagopalachari to fulfil this task. ${ }^{88}$ The results were Santhanam's Ambedkar's Attack (1946) and Rajagopalachari's Ambedkar Refuted (1946). ${ }^{89}$ Both books defended the work done by Gandhi in relation to Dalits. They also highlighted that the 1945-46 elections demonstrated that Ambedkar had no real power over Dalits. The publication of these books is an important sign that there were at this point at least two different Congress' attitudes towards Ambedkar. On the one hand, the Gandhians were not ready to show any love towards Ambedkar, let alone invite him to join the new government. On the other, Patel and Nehru were aware of the larger political game at stake. They knew that without Muslims the Indian political space was tilted in their favour. Ambedkar would be left without any significant options of political allies. In short, with the creation of Pakistan, the politics of 'divide and rule' acquired a literal meaning. The two largest minorities were divided and Congress ruled virtually unopposed. 
Rather than an act of good faith from Gandhi and Nehru, Ambedkar's incorporation to the new government responded to mere political calculations. This is also evident in his writings. In a letter to A.V. Alexander, the British Labour politician, Ambedkar revealed to him that people 'who know the mind of the Congress' had approached him to broker a deal. Ambedkar was informed that 'if he was prepared to accept joint electorates, the Congress on its part would be quite prepared to concede all other demands'. ${ }^{90}$ Ambedkar explained to Alexander that such agreement would be futile as without separate electorates, Dalits would be a perpetual political minority. However, as I have shown, Ambedkar joined the government only until he was out of options to secure any type of safeguards for Dalits. In Ambedkar's words:

\footnotetext{
It is a very deep game. Realising that there is no escape from giving the Untouchables some safeguards, the Congress wants to find out some way by which it can make them of no effect. It is in the system of joint electorates that the Congress sees an instrument of making the safeguards of no effect. That is why the Congress is insisting upon joint electorates. For joint electorates means giving the Untouchables office without power. ${ }^{91}$
}

Not surprisingly, after Partition, the questions of separate electorates disappeared from the debating table in India. Ambedkar, who was elected to the Constituent Assembly from Bengal, was in a political limbo after the announcement of the division of the province. Perhaps as a way to keep him close to the administration, Congress made sure to find Ambedkar a place in the new government. For this to happen, Rajendra Prasad wrote to B.G. Kher, the first Chief Minister of Bombay, to ensure Ambedkar's election to the Constituent Assembly. Prasad wanted Ambedkar to occupy the recently vacated seat left by the resignation of M.R. Jayakar, the veteran congressman. Kher was against this move. During the 1930s, he had had bitter feuds with Ambedkar over Western Indian politics. ${ }^{92}$ Despite Kher's reservations, Prasad made it clear to Kher that '[W]e [Congress] have found Dr. Ambedkar's work, both in the Constituent Assembly and the various committees to which he 
was appointed, to be of such an order as to require that we should not be deprived of his service'. Prasad explained that Ambedkar was instructed to 'send his nomination papers' and that 'for the rest I [Prasad] depend upon you [Kher]'. ${ }^{93}$ Ambedkar was elected on 23 July 1947. He ran unopposed and soon thereafter he joined the Constituent Assembly. ${ }^{94}$ Yet, his election came at a price.

Nehru managed to keep Ambedkar in check by incorporating him to his government. Once elected into the Constituent Assembly, Ambedkar adopted the official discourse regarding Pakistan. In September 1947, Ambedkar urged Dalits in Pakistan to return to India. ${ }^{95}$ In the same way, he criticised the Nizam's ambition to remain as an independent state and encouraged Dalits in Hyderabad not to side with the 'enemy'. In his view, the 'Nizam deserves no sympathy in opposing union with India. I am anxious that no person from the Scheduled Castes brings disgrace upon the community by siding with one who is an enemy of India' ${ }^{96}$ This stance highlights once again Ambedkar's political readjustment at this time. His refusal to support the Nizam is strange as the Princely States were also trying to revalidate the agreements they had made with the British before they left India. Thus, Ambedkar was reflecting the official policy of making state sovereignty one of the key objectives of the newly independent country. ${ }^{97}$ Furthermore, when Ambedkar decided to be more critical of Congress's administration, Nehru did not hesitate to establish his authority. For example, in 1948, Ambedkar gave a speech in Lucknow explaining to his followers why he had joined the government. The press reported that the speech was hostile to Congress. When Nehru found out, he demanded a retraction from Ambedkar. Nehru explained that being part of the Cabinet meant having 'a certain goodwill towards the Congress or at least and avoidance of anything that might be construed as an attack on the Congress' ${ }^{98}$ There is no doubt that Nehru was successful. By making him the Chairman of the Constitution Drafting Committee, a role that he would later repudiate, Ambedkar would always be linked 
to the birth of India as a nation. The ubiquitous images and statues of Ambedkar holding the Constitution under his arm are a constant reminder of this.

\section{Conclusion}

This article has shown that the way Ambedkar's politics played out in independent India do not make much sense unless the effects of Partition are taken into account. The last two decades have seen a growth of Ambedkar as a historical figure in India and beyond. On one hand, different Dalit movements and organisations have made Ambedkar a symbol of their struggle. They have documented plenty of his history and have made it accessible to a large non-academic audience. On the other hand, mainstream political organisations in India, including the present ruling party, have appropriated Ambedkar as an icon to appeal to the lower-castes. These narratives depict Ambedkar as a nationalist and as the 'Architect of the Constitution'. They do this despite his work with the government was only a brief stint in a long political career mostly as the opposition. Moreover, Ambedkar is now often placed alongside Gandhi and Nehru as one of the Founding Fathers of Modern India. Even the United Nations, on behalf of the Indian Mission, have started to celebrate Ambedkar's birthday as a day against injustice and inequality.

Together, the Dalit and the nationalist narratives have decontextualized Ambedkar's politics during Partition. By portraying him solely as a hero or as a nationalist, the complex nature of Ambedkar as a politician and as an individual has been largely forgotten. They have also given space for the survival of misleading stories in which Ambedkar joined the Nehru government due to the goodwill of Congress. As it has been shown, Ambedkar resorted to desperate measures in desperate times. He approached a wide range of national and international figures and organisations in order to secure political safeguards for Dalits. Ambedkar saw in Partition the loss of two great political allies, the Muslim League and the Colonial Government. He feared that without the colonial protection and the political support 
of Muslims, Dalits would suffer as they would live in a perpetual 'Hindu Raj'. In such setting, the power of the Hindu majority would be fixed and political alliances would be useless. Despite his efforts, Ambedkar's political alliances did not come through. He was forced to make a decision on how to pursue the interests of his people without the support of Muslims and the British in Independent India and eventually was forced to collaborate with Congress. Thus, to remember Ambedkar only as the Father of the Constitution is doing him a disservice.

\footnotetext{
${ }^{1}$ This article was possible due to an Early Career Research Fellowship funded by the Leverhulme Trust. I would like to thank the editor and reviewers for their invaluable comments. This essay also received precious feedback from Sunil Purushotham and Laura Loyola. All errors are mine.

${ }^{2}$ I use the anachronistic term Dalit throughout the essay except when in quotation. As a general rule, the term Untouchable was used throughout the twentieth century. Before 1935, the term used by the government to refer to these groups was 'Depressed Classes'. After 1935, the category Scheduled Castes was coined and has been in use in official matters since then.

${ }^{3}$ Gaikwad, 'Ambedkar and Indian nationalism', p. 518; Gore, Ambedkar's political and social thought, p. 180; Jaffrelot, Dr Ambedkar and untouchability, p. 100.

${ }^{4}$ Sen, 'Caste politics and Partition in South Asian history'.

${ }^{5}$ Among some of the valuable work on Dalits that covers this period but that do not dwell on the question of Partition are Zelliot, 'Congress and Untouchables, 1915-50'; Gallanter, Competing equalities; Juergensmeyer, Religion as social vision.

${ }^{6}$ Dwaipayan Sen is one of the exceptions, see in particular his work on J.N. Mandal where he argues that the Partition of Bengal intended to break up, at least in some measure, the Dalit-Muslim political alliance in the region. Sen, 'No Matter How, Jogendranath Had to be Defeated'.

${ }^{7}$ Butalia, The other side of silence, p. 223.

${ }^{8}$ Pandey, 'Nobody's People: The Dalits of Punjab in the Forced Removal of 1947'.
} 
${ }^{9}$ Kaur, 'Narrative Absence: An 'Untouchable Account of Partition migration'; and Since 1947: Partition Narratives among Punjabi Migrants of Delhi.

${ }^{10}$ Rawat, 'Making Claims for Power: A New Agenda for Dalit politics in Uttar Pradesh, 1946-48'; and 'Partition politics and Achuut identity: A Study of the Scheduled Castes Federation and Dalit politics in UP, 1946-48'.

${ }^{11}$ Rawat mainly constructs his argument against the one offered by Sekhar Bandyopadhyay in Caste, protest, and identity in colonial India: The Namashudras of Bengal, 1872-1947; and 'From Alienation to Integration: Changes in the Politics of Caste in Bengal, 1937-47'.

12 Bandyopadhyay, 'Transfer of Power and the Crisis of Dalit Politics in India, 1945-47'.

${ }^{13}$ Ibid. p. 940 .

${ }^{14}$ Ibid. p. 941.

${ }^{15}$ Ibid. p. 942.

${ }^{16}$ An interesting exception is Faisal Devji’s work on the interaction between Jinnah, Periyar, Gandhi and Ambedkar. See chapter 5 of Devji, Muslim Zion: Pakistan as a political idea.

${ }^{17}$ An indicator of the fear of losing Untouchables to Islam and Christianity is clear in the growth of the shuddhi (purification and Hindu reconversion) movement undertaken principally by the Arya Samaj in the early twentieth century. See Jaffrelot, Religion, Caste and Politics in India, pp. 147-155; see also Gould, Hindu Nationalism and the Language of Politics in Late Colonial India, pp. 87-130.

${ }^{18}$ See Rahmat Ali. Dinia: The Seventh Continent of the World.

${ }^{19}$ Ambedkar, 'Pakistan or the partition of India'.

${ }^{20}$ Ibid. p. 394.

${ }^{21}$ The implications of the events at this time in South and South East Asia are covered in Bayly and Harper, Forgotten Armies: Britain's Asian Empire and the War with Japan.

${ }^{22}$ For more on the Cripps Mission see Mansergh, 'The Cripps Mission to India, March-April 1942'.

${ }^{23}$ The Bombay Chronicle, 26 February 1942; and Dr Babasaheb Ambedkar Writings and Speeches (hereafter BAWS), Vol. 17(1), p.348.

${ }^{24}$ Ambedkar, 'Statement of Dr. Ambedkar on the Cripps Proposals', BAWS, Vol. 10, p. 462.

${ }^{25}$ Ambedkar, 'Communal Deadlock and the Way to Solve it', BAWS, Vol. 1, pp. 357-79.

${ }^{26}$ See Prasad, India Divided, pp. 383-387. This works shows a good analysis on Congress views about the idea of Pakistan. 
${ }^{27}$ The National Standard, 28 November 1947; BAWS, Vol. 17 (01), p. 368.

${ }^{28}$ For more on this see Papers relating to the Cabinet Mission to India. The Congress also published their own version of events in a selection of documents with a foreword by Rajendra Prasad in Cabinet Mission in India.

${ }^{29}$ Zelliot, Dr. Babasaheb Ambedkar, p. 199.

${ }^{30}$ For more on The Poona Pact see Coward, 'Gandhi, Ambedkar and Untouchability', pp. 41-66.

${ }^{31}$ BAWS, Vol. 17 (02), pp. 238-249. See also Rawat's 'Making Claims for Power'.

${ }^{32}$ Ambedkar 'All-India Scheduled Castes Federation Memorandum Submitted by Dr B.R. Ambedkar to the Cabinet Mission on $5^{\text {th }}$ April 1946' (hereafter 'Memorandum to Cabinet Mission'), BAWS, Vol. 17 (02), pp. 171-187.

${ }^{33}$ BAWS, Vol. 17 (02), p. 506.

${ }^{34}$ Ibid. p. 245.

${ }^{35}$ Ibid. p. 507.

${ }^{36}$ The Bombay Chronicle 25 July 1947.

${ }^{37}$ The full correspondence between Ramsay MacDonald and Gandhi may be found in Pyarelal, The Epic Fast.

${ }^{38}$ See also The Depressed Classes: A Chronological Documentation; and Gupta, The Scheduled Castes in Modern Indian Politics, pp. 293-308.

${ }^{39}$ Ambedkar offers his version of events in, 'What Congress and Gandhi Have Done to the Untouchables', BAWS, Vol. 9.

${ }^{40}$ Churchill Archives (CHAR), Cambridge, Churchill Papers (CHUR), Public and Political: General: Political: Correspondence and Papers on India (March 1946-December 1946) (hereafter Papers on India), CHUR 2/42AB, Fo. 132, Ambedkar to Attlee, 1 July 1946.

${ }^{41}$ Attlee to Ambedkar, $1^{\text {st }}$ August 1946 in BAWS, Vol. 10, p. 509.

${ }^{42}$ Rawat, 'Making Claims for Power', p. 589.

${ }^{43}$ BAWS, Vol. 17 (02), p. 513.

${ }^{44}$ Ibid. p. 516

${ }^{45}$ Ibid.

${ }^{46}$ Ibid. p. 515.

${ }^{47}$ Ibid. p. 519.

${ }^{48}$ For a discussion on Ambedkar's main criticism against the Indian village see Chairez-Garza, 'Touching Space'. 
${ }^{49}$ See the Bombay Depressed Classes and Aboriginal Tribes (Starte) Committee 1929-30.For the Simon

Commission see 'Evidence of Dr. Ambedkar before the Indian Statutory Commission on 23 ${ }^{\text {rd }}$ October 1928', BAWS, Vol. 2, pp. 459-490.

${ }^{50}$ See 'Memorandum submitted to Cabinet Mission’ BAWS, Vol. 17 (02). Pp. 171- 186.

${ }^{51}$ Ibid. p. 176.

${ }^{52}$ Ibid. pp. 178-179.

${ }^{53}$ BAWS Vol. 17 (02) p. 511.

${ }^{54}$ Ibid. 426.

${ }^{55}$ Ambedkar, 'States and Minorities', BAWS, Vol. 1, p. 426.

${ }^{56}$ Ibid. p. 425 .

${ }^{57}$ Ibid.

${ }^{58}$ Ibid.

${ }^{59}$ See Dubow, 'Smuts, the United Nations and the Rhetoric of Race and Rights', p. 47.

${ }^{60}$ The New York Times, 24 June 1946; and Aug 5, 1947.

${ }^{61}$ The New York Times, 28 October 1946.

${ }^{62}$ See South Asian American Digital Archive, Ambedkar to Du Bois, ca. July 1946 and Du Bois to Ambedkar 31, July 1946, https://www.saada.org/search/ambedkar (accessed 4 May 2017). The letters are also available at the Du Bois Papers at the University of Massachusetts.

${ }^{63}$ The Manchester Guardian, 14 November1946.

${ }^{64}$ IOR, Collection 180/80 United Nations Organisation -Complaint to U.N.O. by All-India Scheduled Castes Federation (IOR: L/E/9/1946), C.B.B. Heathcote-Smith to Curson, 30 January 1947.

${ }^{65}$ Ibid. Mr. Rajagopalachari replies to General Smuts 16 November 1946.

${ }^{66}$ Ibid. Curson to C.B.B. Heathcote-Smith, 28 January 1947

${ }^{67}$ Ibid. Brief for Dr. Ambedkar's visit to the UK, 1946.

${ }^{68}$ BAWS, Vol. 2, p. 745.

${ }^{69}$ U.K. Parliamentary Papers (ProQuest) website: $20^{\text {th }}$ Century House of Commons Hansard Sessional Papers, Commons Sitting of Thursday, $16^{\text {th }}$ May 1946,

http://parlipapers.proquest.com/parlipapers/docview/t71.d76.cds5cv0422p0-0013?accountid=14664 (accessed 4 May 2017).

${ }^{70}$ CHAR, CHUR, Papers on India, CHUR 2/42A-B, Fo. 48, Ambedkar to Churchill, 17 May 1946. 
${ }^{71}$ Ibid.

${ }^{72}$ Ibid.

${ }^{73}$ CHAR, CHUR, Papers on India, CHUR 2/42A-B, Fo. 131, Ambedkar to Churchill, 2 July 1946.

${ }^{74}$ CHAR, CHUR, Papers on India, CHUR 2/42A-B, Fo. 132, Ambedkar to Attlee, 1 July 1946.

${ }^{75}$ Ibid.

${ }^{76}$ Ibid.

${ }^{77}$ Ibid.

78 Ambedkar to Patel 14 October 1946, BAWS, Vol 21. pp. 228-232.

${ }^{79}$ CHAR, CHUR, Papers on India, CHUR 2/42A-B, Fo. 267, Ambedkar to Churchill, 26 October 1946.

${ }^{80}$ CHAR, CHUR, Public and Political: General: Political: Correspondence A-B, CHUR 2/52A-B, Fo. 39, Butler to Churchill, 20 November, 1946.

${ }^{81}$ Nehru speech was given on 13 December 1946.

${ }^{82}$ Ambedkar, 'What Congress and Gandhi Have Done to the Untouchables', BAWS, Vol. 9.

${ }^{83}$ BAWS, Vol. 13, p. 9.

${ }^{84}$ Ibid.

${ }^{85}$ The National Standard, 26 December 1946.

${ }^{86}$ The Free Press Journal, 5 September 1946.

${ }^{87}$ The Bombay Chronicle, 30 December 1946.

${ }^{88}$ Gandhi to Santhanam, 18 October 1945 and Gandhi to Rajagopalchari 26 August 1945, The Collected Works of Mahatma Gandhi, Vol. 81 pp. 374, 169.

${ }^{89}$ Santhanam, K. Ambedkar's Attack; and Rajagopalachari, C., Ambedkar Refuted.

${ }^{90}$ Ambedkar to Alexander 14 May 1946, BAWS, Vol 10. pp. 495.

${ }^{91}$ Ibid. pp. 495-6.

${ }^{92}$ Ambedkar and Kher disagreed on many issues and had heated debates about the best way to confront untouchability. Apart from this, in 1939, Kher accused Ambedkar of being anti-nationalist for his support to Britain at the time of WWII. See 'On participation in the War', BAWS, Vol. 2, p. 261.

${ }^{93}$ National Archives of India (NAI), New Delhi, Private Papers, Rajendra Prasad Papers, F. No. 1-E/47

(Election of Members in the Constituent Assembly), Prasad to Kher, 30 June 1947.

${ }^{94}$ Dr Ambedkar Source Material, Vol. 1. p. 344.

${ }^{95}$ The Bombay Chronicle, 28 November 1947. 


\footnotetext{
96 The National Standard, 28 November 1947.

${ }^{97}$ See the work of Purushotham, 'Internal Violence: "Police Action" in Hyderabad'.

${ }^{98}$ NAI, Private Papers, Rajendra Prasad Papers, PF. No. 14-C/1948. Nehru to Ambedkar, 30-April 1948.
}

\section{References}

Ali, R. C. Dinia: The Seventh Continent of the World, Cambridge, 1946.

Ambedkar, B.R. 'Pakistan or the Partition of India' in V. Moon, ed., Dr. Babasaheb Ambedkar writings and speeches (hereafter BAWS), Vol 8, Bombay, 2014 [1946].

'States and Minorities' in V. Moon, ed., BAWS, Vol. 1, Bombay, 2014 [1947], p. 426.

'All-India Scheduled Castes Federation Memorandum Submitted by Dr B.R. Ambedkar to the Cabinet

Mission on $5^{\text {th }}$ April 1946' in V. Moon, ed., BAWS, Vol. 17 (02), Bombay, 2014, pp. 171-187.

'What Congress and Gandhi Have Done to the Untouchables' in V. Moon, ed., BAWS, Vol. 9, Bombay, 2014

[1945].

'Evidence of Dr. Ambedkar before the Indian Statutory Commission on $23^{\text {rd }}$ October 1928' in V. Moon, ed., BAWS, Vol. 2, Bombay, 2014, p. 459-490.

Bandyopadhyay, S. Caste, protest, and identity in colonial India: The Namashudras of Bengal, 1872-1947, London, 1997.

'From Alienation to Integration: Changes in the Politics of Caste in Bengal, 1937-47', Indian Economic and Social History Review (IESHR), Vol. 31 (3), 1994, pp. 349-391.

'Transfer of Power and the Crisis of Dalit Politics in India, 1945-47', Modern Asian Studies, Vol. 34 (4), 2000, pp. 893-942.

Bayly, C.A. and Harper, T. Forgotten Armies: Britain's Asian Empire and the War with Japan, London, 2005.

Bombay Depressed Classes and Aboriginal Tribes (Starte) Committee, 1929-30, Bombay, 1930.

Butalia, U. The Other Side of Silence: Voices from the Partition of India, New Delhi, 1998.

Cabinet Mission in India, New Delhi, 1946.

Chairez-Garza, J.F. 'Touching Space: Ambedkar on the Spatial Features of Untouchability', Contemporary South Asia, Vol. 22 (1), 2014, pp. 37-50.

Churchill Archives (CHAR), Cambridge. 
Coward, H. 'Gandhi, Ambedkar and Untouchability' in Harold Coward, ed., Indian critiques of Gandhi, Albany, 2003, pp. 41-66.

Devji, F. Muslim Zion: Pakistan as a Political Idea, London, 2013.

Dubow, S. 'Smuts, the United Nations and the Rhetoric of Race and Rights', Journal of Contemporary History, Vol 43 (1), 2008, pp. 45-74.

Gaikwad, S.M. 'Ambedkar and Indian Nationalism', Economic and Political Weekly (hereafter EPW), 7 March 1998, p. 518.

Gallanter, M. Competing Equalities: The Indian Experience with Compensatory Discrimination, Berkeley, 1980.

Gandhi, M.K. The Collected Works of Mahatma Gandhi, Ahmedabad, 1980, Vol. 81, pp. 374, 169.

Gore, M.S. The Social Context of an Ideology: Ambedkar's Political and Social Thought, New Delhi, 1993.

Gould, W. Hindu Nationalism and the Language of Politics in Late Colonial India, Cambridge, 2004.

Gupta, S.K. The Scheduled Castes in modern Indian politics: Their emergence as a political power, New Delhi, 1985. India Office Records and Papers (IOR), London.

Jaffrelot, C. Dr Ambedkar and Untouchability: Analysing and Fighting Caste, New Delhi, 2005. Religion, Caste and Politics in India, New York, 2011, pp. 147-155;

Juergensmeyer, M. Religion as Social Vision: The Movement against Untouchability in $20^{\text {th }}$ century Punjab Berkeley, 1982.

Kaur, R. 'Narrative absence: An 'Untouchable account of Partition migration', Contributions to Indian Sociology, Vol. 42 (2), 2008, pp. 281-306.

- Since 1947: Partition Narratives among Punjabi Migrants of Delhi, New Delhi/New York, 2007.

Kunte, B.G. and Phatak, B.N., eds, Source Material on Dr Babasaheb Ambedkar and the Movement of Untouchables, Bombay, 1982, pp. 344.

Mansergh, N. 'The Cripps Mission to India, March-April 1942', International Journal, Vol. 26 (2), 1971, pp. 338-46.

Moon, V. ed., BAWS, Vol. 1, New Delhi, 2014.

ed., BAWS, Vol. 2, New Delhi, 2014.

ed., BAWS, Vol. 10, New Delhi, 2014.

ed., BAWS, Vol. 13, New Delhi, 2014.

ed., BAWS, Vol. 17 (1), New Delhi, 2014.

ed., BAWS, Vol. 17 (2), New Delhi, 2014.

Narke, H. ed., BAWS, Vol. 21, Mumbai, 2006. 
National Archives of India (NAI), New Delhi.

Pandey, G. 'Nobody's People: The Dalits of Punjab in the forced removal of 1947' in R. Bessel and C.B. Haake, eds, Removing Peoples: Forced Removal in the Modern World, Oxford, 2009, pp. 297-319.

Papers relating to the Cabinet Mission to India, Delhi, 1946.

Prasad, R. India divided, Bombay, 1947, pp. 383-387.

Purushotham, S. 'Internal Violence: The "Police Action" in Hyderabad', Comparative Studies in Society and History, Vol. 57 (2), 2015, pp. 435-466.

Pyarelal, The Epic Fast, Ahmedabad, 1932.

Rajagopalachari, C., Ambedkar Refuted, Bombay, 1946.

Rawat, R. 'Making Claims for Power: A New Agenda for Dalit Politics in Uttar Pradesh, 1946-48', Modern Asian Studies, Vol. 37 (3), 2003, pp. 585-612

'Partition Politics and Achuut Identity: A study of the Scheduled Castes Federation and Dalit politics in UP, 1946-48', in S. Kaul ed., The Partitions of Memory: The Afterlife of the Division of India, New Delhi, 2001, pp. $111-39$.

Santhanam, K. Ambedkar's Attack: A Critical Examination of Dr Ambebkar's Book: 'What Congress and Gandhi Done to the Untouchables, New Delhi, 1946.

Sen, D. 'Caste politics and Partition in South Asian history', History Compass, Vol. 10 (7), 2012, pp. 512-522.

'No matter how, Jogendranath had to be defeated: The Scheduled Castes Federation and the making of partition in Bengal, 1945-1947', IESHR, Vol 49 (3), 2012, pp. 321-64.

South Asian American Digital Archive, https://www.saada.org/search/ambedkar (accessed 4 May 2017).

The depressed classes: A chronological documentation, Kurseong, 1937.

U.K. Parliamentary Papers (ProQuest) website, http://parlipapers.proquest.com (accessed 4 May 2017).

Zelliot, E. 'Congress and Untouchables, 1915-50', in R. Sisson and S. Wolpert, eds, Congress and Indian Nationalism: The pre-Independence Phase, Berkeley, 1988.

- Dr. Babasaheb Ambedkar and the Untouchable movement, New Delhi, 2004. 